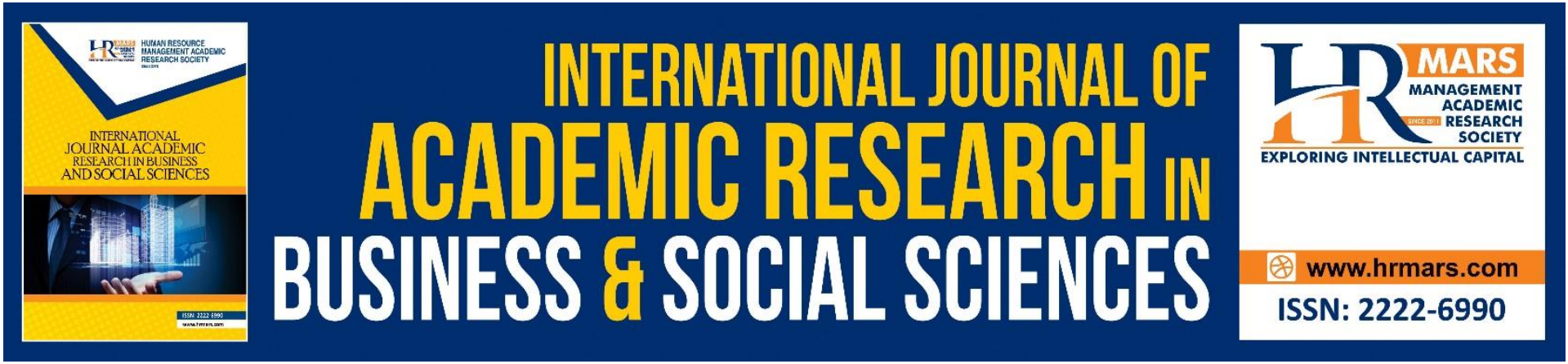

\title{
Capital Adequacy, Cost Income Ratio and Performance of Banks in Ghana
}

Frank Antwi

To Link this Article: http://dx.doi.org/10.6007/IJARBSS/v9-i10/6471

DOI: 10.6007/IJARBSS/v9-i10/6471

Received: 05 September 2019, Revised: 25 September 2019, Accepted: 04 October 2019

Published Online: 31 Oct 2019

In-Text Citation: (Antwi, 2019)

To Cite this Article: Antwi, F. (2019). Capital Adequacy, Cost Income Ratio and Performance of Banks in Ghana. International Journal of Academic Research in Business and Social Sciences, 9(10), 168-184.

Copyright: (C) 2019 The Author(s)

Published by Human Resource Management Academic Research Society (www.hrmars.com)

This article is published under the Creative Commons Attribution (CC BY 4.0) license. Anyone may reproduce, distribute, translate and create derivative works of this article (for both commercial and non-commercial purposes), subject to full attribution to the original publication and authors. The full terms of this license may be seen at: http://creativecommons.org/licences/by/4.0/legalcode

Vol. 9, No. 10, 2019, Pg. 168 - 184

Full Terms \& Conditions of access and use can be found at http://hrmars.com/index.php/pages/detail/publication-ethics

\section{Capital Adequacy, Cost Income Ratio and Performance of Banks in Ghana}




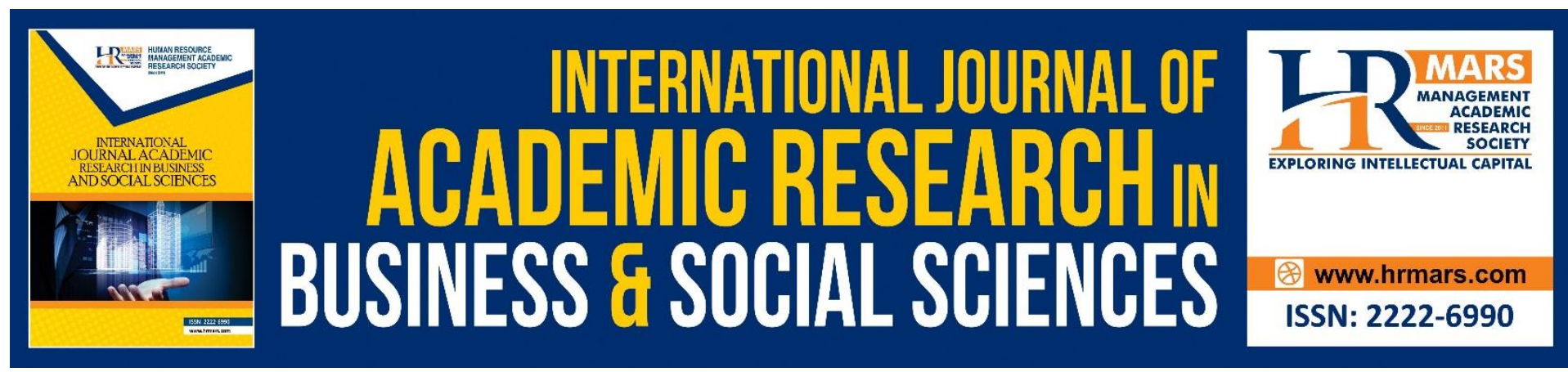

\section{Frank Antwi}

School of Finance and Economics, Jiangsu University, China

Email: Frank.fordjour@yahoo.com,fantwi@pentvars.edu.gh

\section{Abstract}

This paper examines the relationship between Capital adequacy, Cost Income ratio and performance of banks in Ghana. The study uses a sample of banks listed on the Ghana Stock Exchange and data for the periods ending 2013 and 2018 was gathered from their annual reports and regression analysis was carried out using Statistical Software Package, STATA version 15.

The study revealed that capital adequacy is negatively related to performance, as measured by return on assets (ROA) and return on equity (ROE). However, it is statistically insignificant against return on assets but significant in the case of return on equity. The study also revealed that cost-income ratio has a negative relationship with ROA and ROE and it is statistically significant.

For total debt to equity, it is negatively related to ROA and ROE. However, the relationship is statistically significant in the case of ROA but insignificant in the case of ROE. Also, bank size has a negative relationship with performance, both ROA and ROE and it is statistically significant. Lastly, assets growth has a positive relation with both ROA and ROE but it is statistically insignificant in the case of ROA and statistically significant in the case of ROE.

Keywords: Capital Adequacy, Cost-Income Ratio, Performance, Profitability, and Ghana.

\section{Introduction}

The roles of banks in the economic growth and development of an economy cannot be disputed as they play a key financial intermediation role, the very reason for their existence (Oino, 2014), by linking up surplus and deficit units in an economy. In the course of this, capital is needed and banks just like any other firms need capital and even more. Capital is very integral in the business of banking and banking regulators across the globe pay much attention to this hence the capital adequacy of banks is highly regulated. Capital adequacy has been a topic for discussion for decades and it has even become more frequent after the 2008 economic crunch. Generally, adequate capitalization is seen as an important variable in the business of banking and banks must have enough capital to provide funds for their daily needs, sustainability, expansion, as well as protecting depositors' funds. In that, it serves as a source of confidence booster, that is, it provides the customer, the public and the regulatory authority with confidence in the continued financial ability of the bank.

The Bank of Ghana (BoG) which is the regulatory body of the banks in Ghana directed the banks to commence the implementation of BASEL II which sole aim is to ensure stricter capital guidelines and this directive had 1 July 2018 as its effective compliance date. Also, the recapitalization exercise embarked upon by the Bank of Ghana which sought to increase the minimum capital requirement to $\mathrm{Gh} \$ 400 \mathrm{~m}$ attest to the fact that regulators see capital as relevant and something that can affect the continuous existence or otherwise of a bank since 
it may affect its profitability level. Without profits, no firm can survive and attract outside capital to meet its investment target in a competitive environment. The profitability level of a bank is determined by a number of factors and researchers have indicated internal and external factors that can affect profitability. Athanasoglou and Delis (2006) posited that profitability is a function of internal factors and that they are mainly influenced by a bank's management decisions and policy objectives such as the level of liquidity, capital adequacy, provisioning policy, expense management and bank size. On the external factors, they posited that those are related to industrial structural factors such as ownership, stock market development and market concentration as well as other macroeconomic factors. However, for the purposes of this study, only the internal factors are used since they are the areas that the banks are expected to differ in as compared to the external factors since they are not firm-specific but affects all firms in the industry.

Some available literature including Irawati, Maksum, Sadalia and Muda (2019) shows that there is a significant relationship between capital adequacy and others give different results. Again, the direction of the relationship has not been conclusive and some researchers have posited positive whiles others posited negative relationship. Considering this, the current study is conducted to assess this relationship in the context of the Ghanaian banking industry with a special attention on the last six years prior to the recent recapitalisation in the said sector which has gained monumental attention among policymakers, practitioners and academicians. This study also introduces the cost-income ratio and considers the period immediate to the recent recapitalisation to confirm or reject any significant relationship between capital adequacy, cost-income and firm performance.

The remainder of the study is organized into the following sections: Section 2 provides a review of related literature, Section 3 covers data organization and analysis, Section 4 presents findings and discussions and lastly, Section 5 ends the study with conclusion.

\section{Literature Review}

There are several studies that explain the relationship between capital adequacy and other financial indicators and the empirical relationship between capital adequacy and bank performance has been a subject of interest in academic debate in both developed and emerging markets with mixed findings. This section of the study is centered on reviewing such related studies for the purpose of enlightening the researcher and readers of this study.

\section{Firm Performance}

Performance is the ability of an entity to obtain and manage the scarce resources in several different ways to develop a competitive advantage. Generally, literature distinguishes between two types of performance, that is, financial or economic performance and innovative performance and the former is the focus of attention in this study. Bhunia, Mukhuti and Roy (2011) defined financial performance as firm's overall financial health over a given period of time. Financial performance of a firm over a period can be determined by doing financial performance analysis using the acceptable ratios. And with this, Bhunia et al (2011) affirmed that financial performance analysis is the process of determining the operating and financial characteristics of a firm from accounting and financial statements and that the analyst attempts to measure the firm's performance indicators in the interest of stakeholders. In this study, performance (profitability) is measured by return on assets (ROA) and return on equity (ROE). 


\section{Capital Adequacy and Bank Performance}

Bank capital is those fund attributed to the proprietors as published in the balance sheet (Nwankwo, 1991). A bank's equity capital depicts its ability to absorb losses on their books. Berger (1995) found evidence for a positive relationship between the ratios of capital to assets and returns on equity. He argued that a higher capital ratio (with reduced risk of bankruptcy) should reduce a bank's cost of funds, both by reducing the price of funds and the quantity of funds required, that is, improving a bank's net interest income and hence profitability. Neceur (2003) using a sample of 10 Tunisian banks from 1980 to 2000 and a panel linear regression model, reported a strong positive impact of capitalization to ROA. Sufian and Chong (2008) also reported the same results after examining the impact of capital to the profitability of banks in Philippines from 1990 to 2005. Again, Syafri et al. (2012) analyzed the factors that affect the profit of commercial banks in Indonesia. The empirical results show that there is a positive and significant relationship between banks' profitability total equity to total assets. According to Staikouras and Wood (2003), there exist a positive link between a greater equity and profitability among EU banks. Other studies support the positive relationship between capital adequacy ratio and bank performance (Abreu and Mendes, 2001; Naceur \& Kandil, 2009; Goddard, Molyneux and Wilson, 2004; Irawati et al, 2019).

On the other hand, other studies on capital adequacy as a determinant of profitability of banks revealed that a high capital adequacy ratio should signify a bank that is operating over-cautiously and ignoring potentially profitable trading opportunities (Goddard, Molyneux, and Wilson 2004), which implies a negative relationship between equity to asset ratio and bank performance. At the same time, banks with higher equity to asset ratio will normally have lower needs of external funding and therefore higher profitability (Pasiouras and Kosmidou, 2007). Blum (1999) posited that in some cases, regulations that seek to increase capital may reduce bank profits and increase risks. The reason being that banks usually generate most of their revenue through financial intermediation which includes liquidity transformation and part of this revenue may be retained as reserves to supplement capital. Navapan and Tripe (2003) indicated that the negative relationship between a bank's ratio of capital to assets and its return on equity may seem to be self-evident and does not need empirical verification. In addition, they found a negative relationship between capital and profitability.

According to Almazari, (2013), the return on assets ratio (ROA) is negatively correlated with total equity capital to total assets ratio (ECA) but positively correlated with debt to equity ratio (DE) and bank size (BS) among banks in Saudi Arabia. He also found that the return on equity ratio (ROE) is negatively correlated with total equity capital to total assets ratio (ECA). Barnor and Odonkor (2013), also indicated a negative and insignificant relationship between capital adequacy ratio (ECA) and bank performance (Return on Assets (ROA)) and a negative but significant relationship between capital adequacy ratio (ECA) and performance (Return on Equity (ROE)) among banks in Ghana. The direction of the relationship between bank capital and bank profitability cannot be unanimously predicted in advance. This makes it imperative to conduct a search of this nature to corroborate the previous findings primarily in the context of the Ghanaian banking industry especially at a time that capitalisation has become a chief topic in the debate among the populace and Bank of Ghana haven revoked 
licences of some Ghanaian commercial banks based on low capital adequacy levels. The study hypotheses that:

$\boldsymbol{H}_{1}$ : Capital adequacy is negatively related to bank performance as measured by ROA.

$\mathrm{H}_{2}$ : Capital adequacy is negatively related to bank performance as measured by $R O E$.

\section{Cost-Income Ratio and Performance}

According to Neceur (2003), there is a positive and significant relationship between overheads costs and profitability which is an indication that such costs are probably passed on to depositors and lenders by way of lower deposits rates/or higher lending rates. In a market that is less competitive where selected banks enjoy market power, costs are passed on to customers; hence there would be a positive correlation between overheads costs and profitability (Flamini et al, 2009). However, Sufian and Chong (2008), posited that poor expenses management is a main contributor to poor profitability and they argued that there is a strong relationship between efficient management of expenses and firm performance. Hess and Francis (2004) also found that there is an inverse relationship between the cost income ratio and the bank's profitability. Again, Syafri et al. (2012) revealed that cost-toincome ratio has negative effect on profitability and this was augmented by Almazari, (2013) who also found that Cost-income ratio (CIR) has a negative relationship with ROA. This leads to the hypothesis that:

$\boldsymbol{H}_{3}$ : Cost-income ratio is negatively related to bank performance.

\section{Methodology}

Data was gathered from secondary sources, specifically from the audited and published annual reports of the banks understudy covering the period, 2013 to 2018. The annual reports were extracted from the various newspapers, the websites and the annual report publications of the banks. These data were used to compute key financial ratios of the selected banks for the mentioned period. For data availability purposes, only 6 out of the 9 representing $66.67 \%$ of listed banks on the Ghana Stock Exchange (GSE) were selected as a sample for the study.

\section{Regression Model}

This study examines the impact of capital adequacy and cost-income efficiency on firm performance using listed banks in Ghana. The estimator for the ROA and ROE working models depended on the outcome of the model specification test. For this purpose, the Durbin-WuHausman specification test was conducted and the result was statistically significant at $\alpha=5 \%$. The study therefore chose the fixed effects model as against the random effect model proposed by Torres-Reynia (2007) in such a situation. The following regression equations (1 and 2) were estimated to identify the effect of the independent variables on the dependent variable. These models are based on the work of Mathuva (2009) and Almazari (2013). However, capital adequacy is measured with only one variable in this study since the tests conducted showed extremely high correlation between the other capital adequacy variables used by the aforementioned researchers, hence they were dropped.

$R O A_{i, t}=\alpha_{i}+\beta_{1} E C A_{i, t}+\beta_{2} C I R_{i, t}+\beta_{3} D E_{i, t}+\beta_{4} B S_{i, t}+\beta_{5} G S_{i, t}+\varepsilon_{i, t}$

$R O E_{i, t}=\alpha_{i}+\beta_{1} E C A_{i, t}+\beta_{2} C I R_{i, t}+\beta_{3} D E_{i, t}+\beta_{4} B S_{i, t}+\beta_{5} G S_{i, t}+\varepsilon_{i, t}$

Where:

ROA represents Return on Asset for bank i at time t. 
ROE represents Return on Equity for bank $i$ at time $t$.

ECA represents Total Equity Capital to Total Assets Ratio i at time t.

CIR represents Cost to Income Ratio for bank $i$ at time $t$.

$D E$ represents Debt to Equity Ratio for bank $i$ at time $t$.

AG represents assets growth for $i$ at time $t$

$B S$ represents Bank size for bank $i$ at time $t$.

$\mathrm{i}=1$ to 6 banks.

$\mathrm{t}=$ 2013-2018.

$\mathrm{u}=$ Error term.

\section{The Dependent Variable of this Study}

Per available literature, bank profitability is typically measured by return on assets $(R O A)$, and return on equity (ROE) amidst others such as Net Interest Income. From regulators' perspective, ROA is the best measure of bank profitability (Hassan and Bashir, 2003) and this is also in agreement with the findings of Rivard and Thomas (1997) who posit that bank profitability is best measured by ROA. Others including Turkson, (2011) also posit that the use of ROE is appropriate considering the fact that it determines the shareholders' portion of the profit rather than all the profitability that comes to the firm as measured by ROA. In this current study, both measures of profitability, ROA and ROE are used as dependent variables in separate models as indicated earlier.

\section{The Main Independent Variables \\ Capital Adequacy}

It has been argued that a well-capitalised bank is able to attract cheaper deposits and the likelihood of bankruptcy is minimal. It indicates the ability of a bank to absorb unexpected losses (Javaid et.al, 2011). If a bank has higher levels of equity then cost of capital would decrease (Molyneux and Thorton, 1992), which in effect will have a positive impact on bank profitability. In literature, the equity to asset ratio which is measured by total equity over total asset is used as proxy for capital adequacy. The current study also uses the same proxy for capital adequacy, that is, total equity capital to total assets ratio (ECA).

\section{Cost to Income Ratio (CIR)}

There is a relationship between efficiency as measured by the cost to income ratio and profitability as per literature. In reviewing its operational efficiency, the cost to income ratio, which is defined by operating expenses divided by operating income, can be used for benchmarking by the bank. A study by Hess and Francis (2004) revealed that there is a negative relationship between the cost income ratio and the bank's profitability. This position was supported by Ghosh et al. (2003) who posited that the expected negative relation between efficiency and the cost-income ratio seems to exist. Cost income ratio (CIR), despite its limitations (Welch, 2006), has emerged as another measure of bank's efficiency and a benchmarking metric (Hess and Francis, 2004).

\section{Control variables}

Control variables used in this study include Debt to Equity Ratio (DE), Assets Growth and Bank Size. These are some of the frequently used determinants in analysing banks 
performance (Muthuva 2009; Almazari 2013; Christian et al 2008). All variables used in the study are as described in Table 1 below.

Table 1: Variable Definition

\begin{tabular}{|l|l|}
\hline Variable & Measurement \\
\hline Return on Assets & Net income/Total assets \\
\hline Return on Equity & Net Income/Total Equity \\
\hline Total Equity Capital to Total Assets Ratio (ECA) & Total Equity/Total Assets \\
\hline Cost to Income Ratio (CIR) & Operating expenses/Operating Income \\
\hline Debt to Equity Ratio (DE) & Total Debt/Total Equity \\
\hline Asset Growth (AG) & $\begin{array}{l}\text { (This year's total assets-previous year's } \\
\text { total asset)/previous year's total assets }\end{array}$ \\
\hline Bank size (BS) & Natural Logarithm of Total Assets \\
\hline
\end{tabular}

\section{Empirical Results}

\section{Test for Multi-Collinearity}

To develop the panel analysis, the researchers analysed the inflation factor of the variance, which was necessary to prove that there was low collinearity. That is, with the use of Variance Inflation Factor (VIF) or the degree of Tolerance (1/VIF), a test for multicollinearity was carried out. Multi-collinearity occurs when there is a significant correlation between variables in a given model. The decision rule was that, a variable that has a VIF greater than 10 (VIF>10) or a degree of tolerance less than $0.1(1 / \mathrm{VIF}<0.1)$ was considered to be significantly or highly collinear with other explanatory variables. As seen in table 2 below, the VIFs and their corresponding degree of tolerance (1/VIF) for ECA, CIR, DE, BS, and AG show that they are not highly correlated with each other since none of them has a VIF up to 10 or less than a degree of tolerance of 0.1 .

Table 2: VIF and Tolerance Test

\begin{tabular}{|l|l|l|}
\hline Variable & VIF & $\mathbf{1 / V I F}$ \\
\hline ECA & 4.48 & 0.223364 \\
\hline CIR & 1.15 & 0.871254 \\
\hline DE & 2.34 & 0.427490 \\
\hline BS & 3.22 & 0.310489 \\
\hline AG & 3.53 & 0.283025 \\
\hline Mean VIF & 2.94 & \\
\hline
\end{tabular}

\section{Source: Computations from Research Data,2019}

\section{Test for Data Normality}

The Shapiro and Wilk (1965) test was conducted to test for normality and the result is presented in Table 3. As depicted in Table 3, the z-values for DE and BS are insignificant at $\alpha=5 \%$ and the study therefore accepted the null hypothesis that, the data values of DE and BS came from a normally distributed population and concluded that, the data values of the aforementioned variables were normally distributed. However, the z-values of ROA, ROE, $E C A, C I R$ and $A G$ were statistically significant at $\alpha=5 \%$. Hence, the study failed to accept the null hypothesis that, the data values of ROA, ROE, ECA, CIR and AG came from a normally 
distributed population and concluded that, the data values were not normally distributed. The study therefore adopted a more robust regression estimator which is seen as preferred for the data values of the study since such estimators correct the issue of data abnormality in the classical regression analysis.

Table 3: Shapiro-Wilk test for Data Normality

\begin{tabular}{|l|l|l|l|l|l|}
\hline Variable & Obs. & W & V & V & Prob $>\mathbf{Z}$ \\
\hline ROA & 36 & 0.92162 & 2.858 & 2.196 & 0.01405 \\
\hline ROE & 36 & 0.92459 & 2.750 & 2.115 & 0.01721 \\
\hline ECA & 36 & 0.86473 & 4.933 & 3.337 & 0.00042 \\
\hline CIR & 36 & 0.87716 & 4.479 & 3.135 & 0.00086 \\
\hline DE & 36 & 0.97116 & 1.052 & 0.106 & 0.45795 \\
\hline BS & 36 & 0.95669 & 1.579 & 0.956 & 0.16964 \\
\hline AG & 36 & 0.55641 & 16.175 & 5.820 & 0.00000 \\
\hline
\end{tabular}

Source: Computations from Research Data,2019

\section{Test for Heteroscedasticity}

Breusch and Pagan (1979) and Cook and Weisberg (1983) tests which test for the null hypothesis of homoscedasticity or the lack of heteroscedasticity in linear regression models, was carried out. As indicated in Table 4 below, the results show that the chi2 value of 1.15 for the ROA working model turned out to be statistically insignificant at $\alpha=5 \%$ [( $p=0.2834)>0.05]$. Again, the chi2 value of 1.90 for the ROE working model turned out to be statistically insignificant at $\alpha=5 \%[(p=0.1677)>0.05]$. Therefore, the study failed to reject the null hypothesis of the absence of heteroscedasticity among the fitted values of the ROA and ROE working models, and concluded that there was no heteroscedasticity among the fitted values of the models.

Table 4: Heteroscedasticity

\begin{tabular}{|l|l|l|}
\hline Model & Chi2 (1) & Prob > Chi2 \\
\hline ROA & 1.15 & 0.2834 \\
\hline ROE & 1.90 & 0.1677 \\
\hline
\end{tabular}

Source: Computations from Research Data,2019

\section{Test for Serial Correlation}

To test for serial correlation, the Durbin-Watson test was carried out to test the null hypothesis that, the errors are serially uncorrelated as against the alternative hypothesis which states that, the errors are serially correlated (Durbin \& Watson, 1950; Durbin \& Watson, 1951). The test produces a d-statistic with a value from 0 to 4 where; if the value is 2 , there is no autocorrelation, 0 to $<2$ means positive autocorrelation, and $>2$ to 4 shows that a negative autocorrelation is detected in the sample. From Table $5, d$-statistic value for ROA and ROE were 0.8655152 and 0.8556015 respectively and therefore, the study failed to accept the null hypothesis that, the errors were serially uncorrelated and concluded that there existed first order positive autocorrelation in the sample. Based on this, a more robust regression estimator was viewed as the best for estimating the study's working models, i.e. ROA and ROE working models. 
Table 5: Serial correlation

\begin{tabular}{|l|l|}
\hline Model & Durbin-Watson d-statistic \\
\hline ROA & 0.8655152 \\
\hline ROE & 0.8556015 \\
\hline
\end{tabular}

Source: Computations from Research Data,2019

\section{Model Specification}

The researchers carried out a model specification test. The Durbin-Wu-Hausman test with the null hypothesis that the random effects model is preferred to that of the fixed effects model (Durbin, 1954; Wu, 1973; Hausman, 1978; and Greene, 2012), was used to make a choice for the ROA and ROE working models. In Table 6, the model specification test for ROA and ROE working models showed a Chi2 of 125.40 and 409.84 respectively which were statistically significant at $\alpha=5 \%$ [ch $2(5)=125.40 ; 409.84(p=0000)<0.05]$. Hence, the study rejected the null hypothesis that, the random effects model was preferred against the fixed effects model and concluded that, the Robust Fixed Effects estimator was the best fit for the ROA and ROE working models.

Table 6: Model Specification

\begin{tabular}{|l|l|l|}
\hline Variable & chi2(5) & Prob>chi2 \\
\hline ROA & 125.40 & 0.0000 \\
\hline ROE & 409.84 & 0.0000 \\
\hline
\end{tabular}

Source: Computations from Research Data,2019

\section{Descriptive Statistics}

The mean, standard deviation, minimum and maximum value for each of the variables used in this study are presented in Table 7. As shown in Table 7, the ROA and ROE which proxy performance show averages of 0.048 and 0.320 respectively. This shows that on the average, return on equity (ROE) is higher than return on assets(ROA) by way of bank performance. However, ROE appeared more volatile and unstable with a deviation of 0.218 from the mean (0.320), with a minimum of -0.301 and a maximum of 0.696 , compared to a deviation of 0.034 in relation to ROA with a minimum and maximum values of -0.047 and 0.092 respectively. Capital adequacy, with total equity to total assets used as surrogate reveals that the sampled banks had a mean of 0.149 with a variation of 0.032 , a minimum value of 0.018 and a maximum of 0.218 . The indication here is that some banks were less capitalized whiles others were more capitalized.

The result also indicates that the sampled banks had a mean value of 0.648 for cost income ratio(CIR) with a deviation of 0.245 and 0.335 minimum and a maximum of 1.381 . Also, the mean of debt to equity (DE) is 5.662 with a standard deviation of 1.020 and minimum and maximum values of 3.597 and 7.681 respectively. In terms of bank size, the mean is 15.222 , standard deviation is 0.665 and a minimum and maximum size ranging between 13.807 and 17.383. Lastly, the results show that the sampled banks had assets growth of 0.027 on average with minimum assets growth of -07.676 as against maximum growth of 10.067 . That is, some banks had their assets increased whiles others' decreased. 
Table 7: Descriptive Statistics

\begin{tabular}{|l|l|l|l|l|l|l|l|}
\hline Variables & ROA & ROE & ECA & CIR & DE & BS & AG \\
\hline Mean & 0.048 & 0.320 & 0.149 & 0.648 & 5.662 & 15.222 & 0.027 \\
\hline Stnd. Dev & 0.034 & 0.218 & 0.032 & 0.245 & 1.020 & 0.665 & 2.302 \\
\hline Minimum & -0.047 & -0.301 & 0.018 & 0.335 & 3.597 & 13.807 & -7.676 \\
\hline Maximum & 0.092 & 0.696 & 0.218 & 1.381 & 7.861 & 17.383 & $\begin{array}{l}10.06 \\
7\end{array}$ \\
\hline $\begin{array}{l}\text { Observation } \\
\text { s }\end{array}$ & 36 & 36 & 36 & 36 & 36 & 36 & 36 \\
\hline
\end{tabular}

Source: Computations from Research Data,2019

\section{Regression Results}

To assess the effect of capital adequacy and cost-income ratio on firm performance, ROA and ROE were separately regressed on ECA, CIR, DE, BS and AG. Table 8 and 9 show the outcome of the regressions of the dependent variables ROA and ROE respectively.

\section{Regression with ROA as Dependent Variable}

The first model regressed ROA on the independent variables and the results indicates that ECA which represents capital adequacy measured as total equity divided by total assets entered the regression negative but statistically insignificant. That is, ECA has an inverse relationship with ROA but it is statistically insignificant.

CIR which represents cost-income ratio has negative relationship with ROA and it is statistically significant at $1 \%$ significance level. The measures of debt to equity ratio(DE) and bank size (BS) have negative coefficients and are statistically significant at $5 \%$ significance level. However, AG which measures assets growth turned out to be positively related to ROA but statistically insignificant at $5 \%$ significance level.

The overall R-squared (R2) value of 0.7531 depicts that, the explanatory variable accounted for $75.3 \%$ of the variations in ROA, whilst the unexplained variations [ $24.7 \%$ (10075.3] were accounted for by other inherent variabilities. The overall $R 2$ value was statistically significant at $\alpha=1 \%$. Fitting the coefficients into the ROA regression model, the final model became;

$R O A_{i, t}=0.4339944-0.045889 E C A_{i, t}-0.1196159 C I R_{i, t}-0.0056217 D E_{i, t}-$ $0.0177211 B S_{i, t}+0.0016445 A G_{i, t}+\varepsilon_{i, t}$

(3)

Table 8: Regression with ROA as dependent variable

\begin{tabular}{|l|l|l|l|l|}
\hline Variable & Coef.( $\boldsymbol{\beta})$ & Robust Std. Err & $\mathbf{t}$ & $\mathbf{P}>|\mathbf{t}|$ \\
\hline ECA & -0.045889 & 0.0644238 & -0.71 & 0.508 \\
\hline CIR & -0.1196159 & 0.0082987 & -14.41 & $0.000^{* * *}$ \\
\hline DE & -0.0056217 & 0.0016439 & -3.42 & $0.019^{* *}$ \\
\hline BS & -0.0177211 & 0.005209 & -3.40 & $0.019^{* *}$ \\
\hline AG & 0.0016445 & 0.0008309 & 1.98 & 0.105 \\
\hline CONS & 0.4339944 & 0.0954389 & 4.55 & 0.001 \\
\hline R-squared: & & & & \\
\hline
\end{tabular}




\begin{tabular}{|l|l|l|l|l|}
\hline Within & 0.9543 & Prob > F & 0.0000 & \\
\hline Between & 0.5328 & Number of obs. & 36 & \\
\hline Overall & 0.7531 & Number of groups & 6 & \\
\hline
\end{tabular}

\section{Source: Computations from Research Data,2019}

$* * *$, and $* *$ denotes significance at $1 \%$, and $5 \%$ respectively.

\section{Regression with ROE as Dependent Variable}

Table 9 depicts the results of the regression analysis carried out, using ROE as the dependent variable. The results show that ECA which represents capital adequacy measured as total equity divided by total assets has a negative coefficient and it is statistically significant in determining the banks performance as measured by ROE. However, the level of influence is not so strong since it is at $10 \%$ significance level compared to $5 \%$ or $1 \%$. Also, the coefficient of $\mathrm{CIR}$ which represents the cost-income ratio has negative relationship with ROE and it is statistically significant in influencing the performance of banking firms.

The coefficient of DE which represents debt equity ratio is negative but statistically insignificant in influencing ROE of banks. Size (BS) of the banks measured by the natural log of total assets has a negative coefficient with ROE and it is statistically significant. Unlike the other variables that are negatively related to ROE, AG which measures assets growth turned out to be positively related to ROE and it is statistically significant at $5 \%$ significance level.

The overall R-squared (R2) value of 0.9437 indicates that, the explanatory variable accounted for $94.4 \%$ of the variations in ROE, whilst the unexplained variations [5.6\% (10094.4)] were accounted for by other inherent variabilities. The overall R2 value was statistically significant at $\alpha=1 \%$. Fitting the coefficients into the ROE working model, the final model became;

$R O E_{i, t}=3.214683-1.494073 E C A_{i, t}-0.7898784 C I R_{i, t}-0.0103114 D E_{i, t}-$ $0.1381352 B S_{i, t}+0.0143322 A G_{i, t}+\varepsilon_{i, t}$

Table 9: Regression with ROE as dependent variable

\begin{tabular}{|l|l|l|l|l|}
\hline Variable & Coef.( $\boldsymbol{\beta})$ & Robust Std. Err & $\mathbf{t}$ & $\mathbf{P}>|\mathbf{t}|$ \\
\hline ECA & -1.494073 & 0.6257187 & -2.39 & $0.063^{*}$ \\
\hline CIR & -0.7898784 & 0.034633 & -22.81 & $0.000^{* * *}$ \\
\hline DE & -0.0103114 & 0.0101036 & -1.02 & 0.354 \\
\hline BS & -0.1381352 & 0.0443085 & -3.12 & $0.026^{* *}$ \\
\hline AG & 0.0143322 & 0.0045949 & 3.12 & $0.026^{* *}$ \\
\hline CONS & 3.214683 & 0.8129423 & 3.95 & 0.011 \\
\hline R-squared: & & & & \\
\hline
\end{tabular}




\begin{tabular}{|l|l|l|l|l|}
\hline Within & 0.9437 & Prob > F & 0.0000 & \\
\hline Between & 0.4868 & Number of obs. & 36 & \\
\hline Overall & 0.6908 & Number of groups & 6 & \\
\hline
\end{tabular}

Source: Computations from Research Data,2019

$* * *, * *$ and $*$ denotes significance at $1 \%, 5 \%$ and $10 \%$, respectively.

\section{Discussions and Test of Hypotheses}

This section discusses the findings of the study in relation to existing and relevant literature. The effect that capital adequacy and cost-income ratio have on firms' performance; ROA and ROE is discussed and conclusion on the study's hypotheses are presented.

\section{Capital Adequacy and Performance}

Capital adequacy is negatively related to both measures of firm performance used in this study, that is, ROA and ROE. The study therefore accepts the null hypothesis that capital adequacy is negatively related to firm performance whether performance is measured by return on assets (ROA) or return on equity (ROE). However, capital adequacy is not significant in determining firm performance when measured by ROA but it is significant when measured by ROE. This is in agreement with Goddard, Molyneux, and Wilson (2004), who found a negative relationship between equity to asset ratio and bank performance. Again, the findings of this current study is in direct agreement with and confirms the findings of Barnor et al., (2013) who indicated a negative and insignificant relationship between capital adequacy ratio (ECA) and bank performance (Return on Assets (ROA)) and a negative but significant relationship between capital adequacy ratio (ECA) and performance (Return on Equity (ROE)) among banks in Ghana. However, the negative relationship as revealed in this study is at variance with the findings of other previous works such as (Neceur, 2003; Sufian and Chong, 2008; Staikouras and Wood, 2003; Almazari, 2013; Goddard et al., 2004; Naceur \& Kandil, 2009; Irawati et al, 2019) who found positive relationship between capital adequacy and firm performance.

\section{Cost-Income Ratio and Performance}

The findings show that cost-income ratio has a negative relationship with both ROA and ROE and it is statistically significant in influencing the performance of banking firms whether performance is measured by ROA or ROE. The study therefore accepts the null hypothesis that there is a negative relationship between cost-income ratio and firm performance. This is in agreement with Hess and Francis (2004) who observed that there is an inverse relationship between the cost income ratio and the bank's profitability. This was also supported by Ghosh et al. (2003) who posited that the negative relation between efficiency and the cost-income ratio seems to exist. Again, Syafri et al. (2012) also found that cost-to-income ratio have negative effect on profitability as measured by ROA. Furthermore, the result supports Almazari (2013), who found that cost income ratio (CIR) is negatively correlated with ROA and ROE. This means that banks who fail to properly manage their level of efficiency as measured by cost income ratio would have their profit negatively affected.

\section{Debt Equity Ratio and Performance}


The results show that total debt to equity $(D E)$ is negatively related to performance, both ROA and ROE. This implies that as the total debt of the company increases, the firm performance also decreases. However, the relationship, is statistically significant in the case of ROA but not ROE. The negative relationship between DE and the two measures of performance is in consonance with Kyereboah-Coleman et al (2007) whose study revealed that debt ratio has a negative relationship with firm performance measured by return on assets (ROA) and Muthuva (2009) who confirmed that that Debt-Equity orientation with ROE has a negative effect. However, it is in contrast with the findings of Almazari (2013) who posited that return on assets (ROA) and return on equity (ROE) are positively correlated to debt to equity ratio (DE).

\section{Bank Size and Performance}

Bank size measured by the natural log of total assets has a negative coefficient with both ROA and ROE and it is statistically significant and this is in support of Gatsi and Akoto (2010) who found that size is important in determining bank profitability. Again, the negative relationship supports previous studies such as (Syafri et al., 2012; Koasmidou, 2008; Spathis et al, 2002) who established empirically negative relation between bank size and profitability. That is, a bank can take advantage of the economies of scale at a certain asset size level, but these economies of scale become exhausted as the bank's size increases. These diseconomies were also reported by Mensah \& Abor, (2013). However, this is in contrast with the findings of other studies (Antwi et al, 2015; Almazari, 2013; Ramlall, 2009; Molyneux and Seth, 1998; Pilloff and Rhoades, 2002) who found a positive relation between bank size and profitability.

\section{Assets Growth and Performance}

AG which measures assets growth turned out to be positively related to both ROA and ROE but statistically insignificant in the case of ROA and statistically significant in the case of ROE. The positive relationship between assets growth and performance is in support of Olatunji and Adegbite (2014) who indicated that investments in fixed assets have strong and positive statistical impact on the profitability of banking sector in Nigeria. However, Chen, Yao and Zhang (2008) revealed that there is a significantly negative relation between firms "asset growth and performance by way of stock returns.

\section{Conclusion}

This study sought to examine the relationship between capital adequacy, cost income ratio and performance of banks listed on the Ghana Stock Exchange (GSE). After carrying out some diagnostic and specification tests to address the basic assumptions of the Classical Linear Regression Model (CLRM) and running the regressions for the two separate working models, ROA and ROE, the study revealed that capital adequacy is negatively related to firm performance whether performance is measured by return on assets (ROA) or return on equity (ROE).

The study also revealed that cost-income ratio has a negative relationship with both ROA and ROE and it is statistically significant in influencing the performance of banks in Ghana. Again, the study revealed that total debt to equity (DE) is negatively related to performance, both ROA and ROE. However, the relationship, is statistically significant in the case of ROA but not ROE. When it comes to bank size, it has a negative relationship with performance, both ROA and ROE and it is statistically significant and therefore, the study 
concludes that firm size is important in determining bank profitability. Lastly, assets growth (AG) had a positive relation with both ROA and ROE but statistically insignificant in the case of ROA and statistically significant in the case of ROE.

This study therefore adds to previous findings that there is a negative relationship between capital adequacy and profitability. However, capital adequacy is statistically insignificant in determining firm performance when measured by ROA and significant when measured by ROE. The negative relationship between capital adequacy and performance in the context of Ghana's banking sector suggests that increasing capital is not the antidote to poor performance and hence much more has to be done to ensure that capital is put to maximum use than just stocking up. Therefore, regulators and practitioners should not be focusing on only pushing banks to increase their capital base as a way of ensuring sustainability but must also strengthen the rules regarding the practical application and optimum use of the available funds. It is also recommended that banks in Ghana endeavour to improve upon their efficiency; cost-income effect in order to increase their profitability considering the fact that poor expenses management is a key determinant of performance.

\section{References}

1. Abreu, M., \& Mendes, V. (2001). Commercial Bank Interest Margins and Profitability: Evidence from E.U Countries. Working paper Series, Porto

2. Almazari, A. A. (2013). Capital Adequacy, Cost Income Ratio and the Performance of Saudi Banks. International Journal of Academic Research in Accounting, Finance, and Management Sciences, 3(4), 284-293

3. Antwi, F., \& Apau, E.V. (2015). Financial Performance of Rural and Community Banks (RCBs) in Ghana. The International Journal of Business \& Management, 3(2), 76-85.

4. Athanasoglou, P. P., \& Delis, M. T. (2006). Determinants of bank profitability in the South Eastern European Region. Working Paper, MPRA. URL: http://mpra.ub.unimuenchen.de/10274/.

5. Barnor, C., \& Odonkor, T. A. (2013). Capital Adequacy and the Performance of Ghanaian Banks. Journal of Business Research, 6(1-2), 105-117.

6. Naceur, B. S., \& Kandil, M. (2009). The impact of capital requirements on banks' cost of intermediation and performance: The case of Egypt. Journal of Economics and Business, 61(1), 70-89.

7. Berger, A. (1995). The relationship between capital and earnings in banking. Journal of Money, Credit and Banking, 27,432-456.

8. Bhunia, A., Mukhuti, S. S., \& Roy, R. G. (2011). Financial Performance Analysis-A Case Study. Current Research Journal of Social Sciences, 3(3): 269-275.

9. Blum, J. (1999). Do Capital Adequacy Requirements Reduce Risks in Banking? Journal of Banking \& Finance, 23(5), 755-771.

10. Breusch, T. S., \& Pagan, A. R. (1979). A simple test for heteroskedasticity and random coefficient variation. Econometrica, 47 (5), 1287-1294.

11. Christian, C., Moffitt, J. S. \& Suberly, L. A. (2008). Fundamental Analysis for Evaluating Bank Performance: What Variables Provide the Greatest Insight into Future Earnings? Journal of Bank Accounting and Finance, 22, 17-24.

12. Durbin, J. (1954). Errors in variables. Review of the International Statistical Institute, $22(1 / 3), 23-32$. 
13. Durbin, J., \& Watson, G. S. (1950). Testing for serial correlation in least squares regression, I. Biometrika, 37(3-4), 409-428.

14. Durbin, J., \& Watson, G. S. (1951). Testing for serial correlation in least squares regression, II. Biometrika, 38(1- 2), 159-179.

15. Flamini, V.C., McDonald \& Schumacher, L. (2009). The determinants of commercial bank profitability in sub-saharan Africa. IMF Working Paper, (International Monetary Fund, African Department, WP/09/15)http://www.imf.org/external/pubs/ft/wp/2009/wp0915.pdf

16. Gatsi, J. G. \& Akoto, R. K. (2010). Capital structure and profitability in Ghanaian banks. Retrieved from: http://ssrn.com/abstract=1618952.

17. Ghosh, S.N., Narain, D.M. \& Sahoo, S. (2003). Capital requirements and bank behaviour: An empirical analysis of Indian public sector banks. J.Int.Dev.,15:145-156. DOI:10.1002/jid.947 URL: http://hdl.handle.net/10.1002/jid.947

18. Goddard, J., Molyneux, P., \& Wilson, J.O.S. (2004). Dynamics of Growth and Profitability in Banking. J. Money Credit Bank. 36, 1069-1090.

19. Greene, W. H. (2012). Estimation and inference in binary choice models. Econometric analysis (Seventh ed.). Boston: Pearson Education, pp. 730-755.

20. Hausman, J. A. (1978). Specification tests in econometrics. Econometrica, 46(6), 12511271.

21. Hess, K., \& Francis, G. (2004). Cost income ratio benchmarking in banking. Benchmarking: An International Journal, 3: 303-319. DOI: http://dx.doi.org/10.1108/14635770410538772.

22. Irawati, N., Maksum, A., Sadalia, I., and Muda, I. (2019). Financial Performance of Indonesian's Banking Industry: The Role of Good Corporate Governance, Capital Adequacy Ratio, Non-Performing Loan and Size. International Journal of Scientific and Technology Research, 8(4), 22-26.

23. Javaid, S., Anwar, J., Zaman, K., \& Gaffor, A. (2011), "Determinants of Bank Profitability in Pakistan: Internal Factor Analysis". Mediterranean Journal of Social Sciences,2(1): 59-78. www.mcser.org/images/ stories/.../saura\%20javaid.pdf.

24. Kosmidou, K. (2008). The determinants of banks' profits in Greece during the period of EU Financial integration. Journal of Managerial Finance. [Online] 34 (3). Available from: http://www.emeraldinsight.com.

25. Kyereboah-Coleman, A., Adjasi, K. D. C., \& Abor, J. (2006). Corporate Governance and Firm Performance: Evidence from Ghanaian Listed Firms. Journal of Corporate Ownership and Control, 4(1): 123-132

26. Mathuva, D. M. (2009). Capital Adequacy, Cost Income Ratio and the Performance of Commercial banks: The Kenyan Scenario. International Journal of Applied Economics and Finance. 3(2), 35-47.

27. Molyneux, P., \& Seth, R. (1998). Foreign banks, profits and commercial credit extension in the United States. Applied Financial Economics, 8, 533-539.

28. Molyneux, P., \& Thorton, J. (1992). The determinants of European bank profitability. Journal of Banking and Finance, 16 (6), 1173-1178. DOI: 10.1016/03784266(92)90065-8

29. Navapan, K. \& Tripe, D. (2003). An exploration of the relationship between bank capital levels and return on equity. Proceeding of the 16th Australasian Finance and Banking Conference, December 2003. Palmerston North, pp: 1-15. Direct Link 
30. Nwankwo, G. O. (1991). Bank Management, Principles and Practice, Malthouse Press Ltd. Lagos

31. Oino, I. (2014). The Significance of Bank Capital and Liquidity on Business Cycles: Empirical Evidence from the UK Banking Sector. Journal of Finance and Economics, 2(3), 01-15.

32. Olatunji, T., \& Adegbite, T. (2014). Investment in Fixed Assets and Firm Profitability: Empirical Evidence from the Nigerian Banking Sector. Asian Journal of Social Sciences and Management Studies, 1(3), 78-82.

33. Pasiouras, F., \& Kosmidou, K. (2007). Factors influencing the profitability of domestic and foreign commercial banks in the European Union. Research in International Business and Finance, 21(2), 222-237.

34. Pilloff, S. J., \& Rhoades, S. A. (2002). Structure and Profitability in Banking Markets. Review of Industrial Organization, 20, 81-98.

35. Ramlall, I. (2009). Bank-Specific, Industry-Specific and Macroeconomic Determinants of Profitability in Taiwanese Banking System: Under Panel Data Estimation. International Research Journal of Finance and Economics, 34, 160-167.

36. Rivard, R. J., Thomas, C. R. (1997). The effect of interstate banking on large bank holding company profitability and risk. Journal of Economics and Business 49(1): 6176.

37. Shapiro, S. S., \& Wilk, M. B. (1965). An analysis of variance test for normality (complete samples). Biometrika, 52 (3-4), 591-611.

38. Spathis, C., Koasmidou, K., \& Doumpos, M. (2002). Assessing Profitability Factors in the Greek Banking System: Amulticriteria methodology. International Transactions in Operational Research, 517-530.

39. Staikouras, C. H., \& Wood, G. (2003). The determinants of bank profitability in Europe, paper presented at the European Applied Business Research Conference, Venice, 9-13 June.

40. Sufian, F., \& Chong, R. R. (2008). Determinants of Bank Profitability in a Developing Economy: Empirical Evidence from Philippines. Asian Academy of Management Journal of Accounting and Finance. [Online] 4(2) pp.91-112. Available from: http:// www.usm.my/journal/aamjaf/vol\%204-2-2008/4-2-5.pdf.

41. Syafri, (2012). Factors Affecting Bank Profitability in Indonesia. The 2012 International Conference on Business and Management, 6-7 September 2012, Phuket-Thailand 236 www.caalinteduorg.com/ibsm2012/.../018Mix-Syaf...

42. Torres-Reyna, O. (2007). Panel data analysis: Fixed and random effects using STATA (v. 4. 2). Retrieved from: http://dss.princeton.edu/training/.

43. Turkson, A. H. (2011). Capital structure and the profitability of selected non-financial firms on the Ghana Stock Exchange. (Unpublished master's dissertation). University of Cape Coast, Cape Coast. Ghana.

44. Welch, P. (2006). Rethinking bank efficiency: The failings of the cost-income efficiency ratio.

http://www.bankecon.com/downloads/BankEcon\%20\%20Rethinking\%20Bank\%20Ef ficiency\%20- \%20synopsis.pdf.

45. Wu, D. (1973). Alternative tests of independence between stochastic regressors and disturbances. Econometrica, 41(4), 733-750. 
INTERNATIONAL JOURNAL OF ACADEMIC RESEARCH IN BUSINESS AND SOCIAL SCIENCES Vol. 9, No. 10, October, 2019, E-ISSN: 2222-6990 @ 2019 HRMARS 